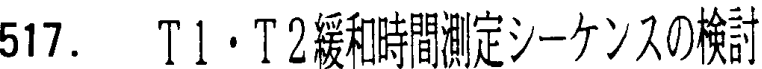

STUDY OF MEASUREMENT SEQUENCE FOR T $1: T 2$ V A L U

\section{香川医科大学附属病院 放射線部}

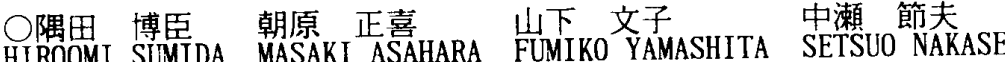

【目的】MR撮影では、色々なシーケンスにおけるパラメー夕の設定は、組織䦔コントラストを付 ける点において大变重要である。また、最近では新しい造影郕等の効果を判定するときにも必要と

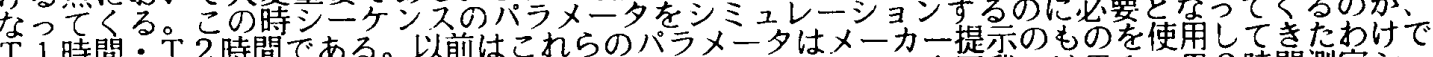

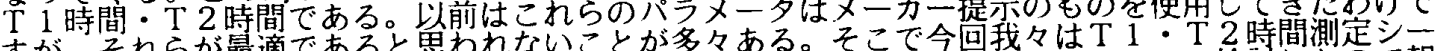

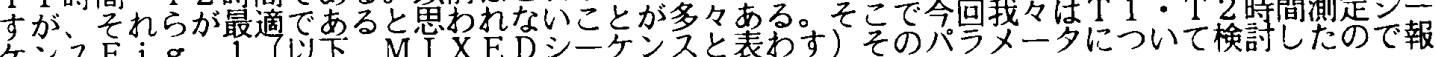
ケンス

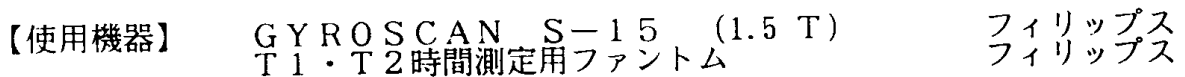

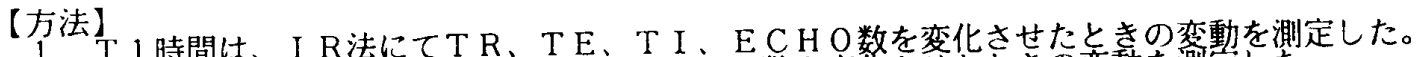

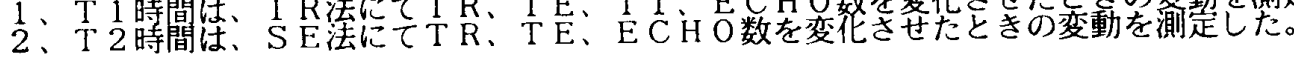

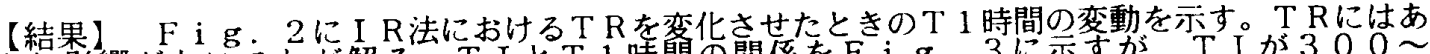

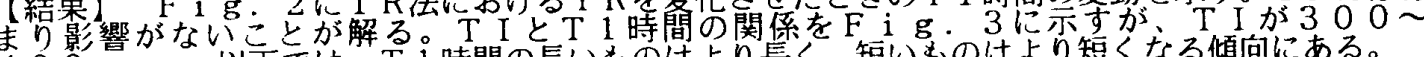
$400 \mathrm{~ms}$ e c 以下では Ti時間の長いものはより長く、短いものはより短くなる傾向にある。

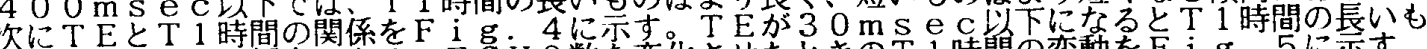

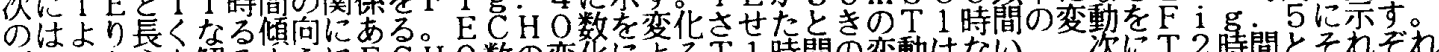
グラフからも解るdうに

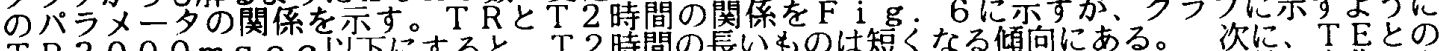

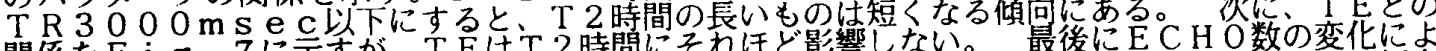

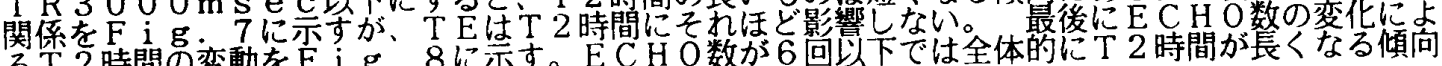
る $\mathrm{T} 2$ 時間

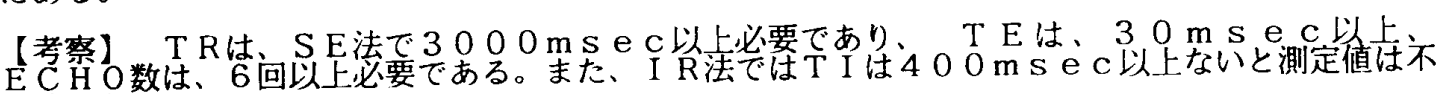
正砗となる。回のグラフで示している破線はメ一カ一の公称值であるが、T 1 時間 $800 \mathrm{~m} \mathrm{sec以}$

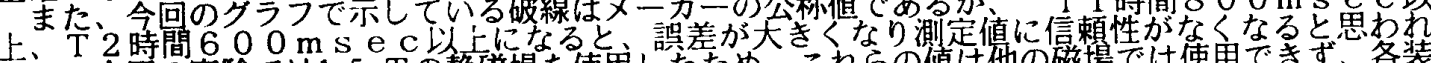
る。今回の実験では1.5 Tの静磁場を使用したため新らの值は他の磁場では使用できず、各装

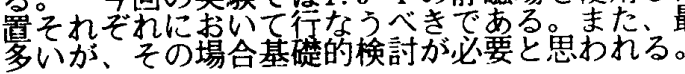

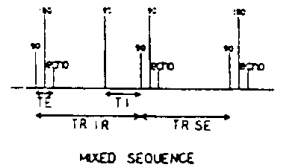

Fig. 1

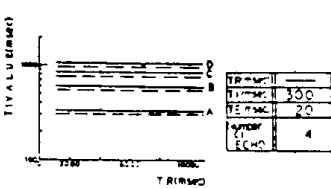

Fig. 2

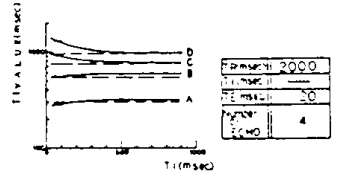

Fig. 3

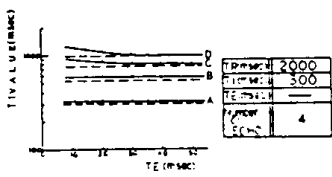

Fig. 4

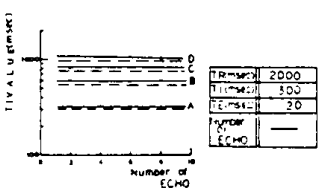

Fig. 5

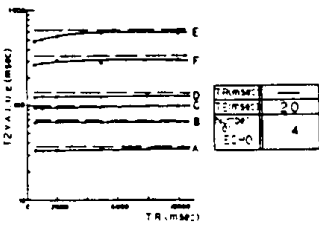

Fig. 6

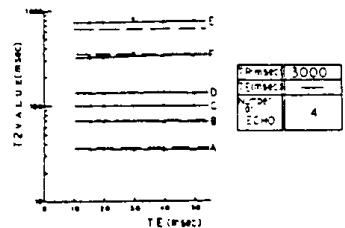

Fig. 7

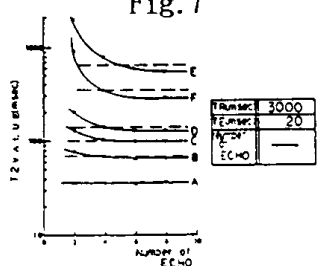

Fig. 8 